Jahangirnagar University J. Biol. Sci. 4(2): 47-51, 2015 (December)

- Short communication

\title{
Ethnomedicinal practice of Tinospora cordifolia (Willd.) Meirs ex Hook f. \& Thoms. by the traditional medicine practitioners at Savar, Dhaka
}

\author{
Fakhruddin Ali Ahmed1, Rokshana Sharmin Bristy and Nusrat Jahan Tasnova \\ Department of Botany, Jahangirnagar University, Savar, Dhaka-1342, Bangladesh
}

Key words: Ethnomedicine, Tinospora cordifolia, Savar Upazilla.

In Bangladesh, inexpensiveness and easy accessibility have made traditional medicine an integral part of public health service (Ahmed et al., 2009, Rahman et al., 2012). Among the vast library of important medicinal plants, Tinospora cordifolia (Willd.) Miers ex Hook f. \& Thoms. belonging to the family Menispermaeceae is immensely valuable in terms of chemical constituent and pharmacology (Srivastava, 2011). T. cordifolia (Gulancha) is a large deciduous, extensively spreading and climbing shrub with a number of coiling branches. It is indigenous to areas of Bangladesh, India, Myanmar, Sri Lanka, China, Thailand, Philippines, Indonesia, Malaysia, Borneo, Vietnam and North-WestSouth Africa (Pendse et al., 1981 and Jain et al., 2010). In the traditional medicine system, whole plant of $T$. cordifolia is used to treat gout and ulcer, jaundice, rheumatism, skin diseases and as a stimulator of bile secretion, diuretic, blood enhancer (Choudhary et al., 2013). This plant is used as vermifuge, antipyretic, antimalarial, for washing sore eyes, syphilitic sores, chronic diarrhea and dysentery (Khory \& Katrak, 1981). Ayurveda advocates the use of $T$. cordifolia stem as rejuvenator and routinely prescribed to treat fever, jaundice, diabetes, chronic diarrhoea, urinary diseases and dyspepsia (Singh et al., 2003). Bishayi (2002) reported the immunomodulatory and antioxidant potential of $T$. cordifolia. T. cordifolia grows almost everywhere in Bangladesh (Choudhury et al., 2013). Uddin \& Hassan (2014) reported the internal application of stem juice as an antianthelmintic from Kalenga forest of Bangladesh.

Savar is an Upazila of Dhaka District, located $\left(23^{\circ} 45^{\prime} \mathrm{N}-24^{\circ} 0^{\prime} \mathrm{N}\right.$ and $\left.90^{\circ} 14^{\prime} \mathrm{E}-90^{\circ} 27^{\prime} \mathrm{E}\right)$ at a distance of about 24 kilometers to the northwest of Dhaka city. The religious breakdown of the local inhabitant of Savar Upazila was $93.86 \%$ Muslim, $5.35 \%$ Hindu, $0.20 \%$ Buddhist, $0.58 \%$ Christian and $0.03 \%$ ethnic minority group (BBS, 2013). However, from the rowdy observation the presence of $T$. cordifolia in Savar Upazilla seems to be on the verge of disappearance which provoked to study the medicinal use of this plant in this area. Considering the above facts a semi-structured survey on $T$. cordifolia was conducted in Savar Upazila.

Ethnomedicinal survey and data collection: In the present study, the survey was carried out at eight selected areas namely, Savar bazar, Nama bazar, Kuturia, Islamnagar, Rangamati (Bismail), Nobinagar, Zirani and Noyarhat of Savar upazila based on density and diversity of local inhabitant.

1Corresponding author E-mail: faahmed_ju@yahoo.com 
The ethnomedicinal survey was carried out on the registered Ayurvedic or Unani doctors, kavirajes and street canvassers accessible at the above mentioned areas under eight different field trips during the year 2012-2013. Data for this study were collected by the researchers themselves using semi-structured questionnaire following the suggested methodology of Martin (2008). Semi structured questionnaire was preferred as it offered both qualitative and quantitative information. Among the three categories of traditional medicine practitioners of the studied area five registered doctors, six kavirajes and six street canvassers were interviewed. Samples of $T$. cordifolia (guloncho) as pointed out by the traditional practitioner were collected in different pouches and finally the plant specimens were identified and authenticated by the Bangladesh National Herbarium (DACB), Mirpur, Dhaka, Bangladesh. The voucher specimen (accession no- DACB39195) has been deposited in DACB for further reference.

The collected information on ethnomedicinal use of $T$. cordifolia at different sites of Savar area have been presented in Table 1.

Table 1. Ethnobotanical information of $T$. cordifolia obtained from three different categories of traditional medicine practitioners at various areas of Savar Upazila

\begin{tabular}{|c|c|c|c|c|}
\hline Site & $\begin{array}{c}\text { Name and age (years) } \\
\text { of informants }\end{array}$ & $\begin{array}{l}\text { Profession } \\
\text { (practicing } \\
\text { year) }\end{array}$ & Used plant part & Uses \\
\hline \multirow[t]{2}{*}{ Savar bazar } & Dabir Miah (57) & RD (6-7) & Leaf juice & To treat burning sensation. \\
\hline & Md. Sujon Miah (27) & $\mathrm{SC}(2-3)$ & Stem paste & To treat fever \\
\hline Nama & Alomgir Moti (47) & $\mathrm{RD}(10-11)$ & Full plant paste & In the treatment of cough \\
\hline \multirow[t]{3}{*}{ bazar } & Mamun Hossain (40) & $\mathrm{RD}(7-8)$ & Stem paste & Treatment of eczema \\
\hline & $\operatorname{Md} \operatorname{Ali}(52)$ & $\mathrm{K}(22)$ & Stem decoction & Treatment of fever \\
\hline & Khabiruddin (60) & $\mathrm{K}(35)$ & Dried fruit powder & $\begin{array}{l}\text { Taken with ghee or honey } \\
\text { as tonic }\end{array}$ \\
\hline \multirow[t]{2}{*}{ Kuturia } & $\begin{array}{l}\text { Amrito Kumar Sarkar } \\
\text { (35) }\end{array}$ & $\mathrm{RD}(5-6)$ & Stem paste & $\begin{array}{l}\text { To treat various skin } \\
\text { diseases }\end{array}$ \\
\hline & Md Shafiqullah (62) & $\mathrm{SC}(27)$ & Old stem decoction & To treat periodic fever \\
\hline \multirow[t]{2}{*}{ Islamnagar } & Md Abdul Malek(37) & K (17) & Warm juice of root & To treat fever \\
\hline & Md Selim Sarkar (35) & $\mathrm{SC}(5-6)$ & Root paste & To treat leprosy \\
\hline $\begin{array}{l}\text { Rangamati, } \\
\text { Bismail }\end{array}$ & Abdul Mannan(43) & $\mathrm{K}(20)$ & Root and stem & Antidote to scorpion bite \\
\hline \multirow[t]{2}{*}{ Nobinagar } & Md Amzad Ali (47) & SC (12-14) & Stem juice & $\begin{array}{l}\text { Orally taken with honey to } \\
\text { treat asthma. }\end{array}$ \\
\hline & Md Robbin (55) & $\mathrm{SC}(25)$ & Root decoction & To treat dysentery \\
\hline \multirow[t]{2}{*}{ Zirani } & Sabur Miah (45) & $\mathrm{RD}(5-6)$ & $\begin{array}{l}\text { Stem and root } \\
\text { powder. }\end{array}$ & $\begin{array}{l}\text { Taken with milk to treat } \\
\text { cancer }\end{array}$ \\
\hline & Md Khurshed Miah (40) & $\mathrm{K}(20)$ & Stem paste & Treatment of Leucorrhoea \\
\hline \multirow[t]{2}{*}{ Noarhat } & Abdus Salam (55) & $\mathrm{K}(27)$ & Leaf juice & $\begin{array}{l}2-3 \text { drops put in the ear to } \\
\text { treat pain in ear }\end{array}$ \\
\hline & Md Hatem Ali (32) & $\mathrm{SC}(10)$ & Stem juice & $\begin{array}{l}\text { To treat various skin } \\
\text { diseases }\end{array}$ \\
\hline
\end{tabular}

Note: $\mathrm{K}=$ kaviraj, $\mathrm{RD}=$ registered doctor, $\mathrm{SC}=$ street canvasser 
Table 2. List of different plant parts mixed with Tinospora cordifolia and their formulation based on the information obtained from three categories of traditional medicine practitioners at various areas of Savar Upazila

\begin{tabular}{|c|c|c|c|c|c|}
\hline \multirow{2}{*}{$\begin{array}{l}\text { Name of the informant } \\
\text { and profession }\end{array}$} & \multicolumn{2}{|c|}{ Associated plant with $T$. cordifolia } & \multirow[t]{2}{*}{ Family } & \multirow{2}{*}{$\begin{array}{l}\text { Used part and } \\
\text { amount }\end{array}$} & \multirow[t]{2}{*}{ Formulation and use } \\
\hline & Scientific name & Common name & & & \\
\hline $\begin{array}{l}\text { Dr. Amrito Kumar } \\
\text { Sarkar } \\
\text { Registered doctor }\end{array}$ & $\begin{array}{l}\text { Azadirachta indica } \\
\text { Terminalia chebula } \\
\text { Terminalia belerica } \\
\text { Phyllanthus emblica } \\
\text { Zingiber officinalis } \\
\text { Piper longum } \\
\text { Trachyspermum ammi } \\
\text { Emblica ribes } \\
\text { Berberis aristata } \\
\text { Cyperus rotundus } \\
\text { Cedrus deodara }\end{array}$ & $\begin{array}{l}\text { Neem } \\
\text { Horitoki } \\
\text { Bohera } \\
\text { Amloki } \\
\text { Ada } \\
\text { Pipul } \\
\text { Jyno } \\
\text { Birango } \\
\text { Daru horidra } \\
\text { Mutha } \\
\text { Devdaru } \\
\end{array}$ & $\begin{array}{l}\text { Meliaceae } \\
\text { Combretaceae } \\
\text { Combretaceae } \\
\text { Euphorbiaceae } \\
\text { Zingiberaceae } \\
\text { Piperaceae } \\
\text { Apiaceae } \\
\text { Primulaceae } \\
\text { Berberidaceae } \\
\text { Cyperaceae } \\
\text { Pinaceae }\end{array}$ & $\begin{array}{l}\text { Bark }(100 \mathrm{~g}) \\
\text { Fruit }(100 \mathrm{~g}) \\
\text { Fruit }(100 \mathrm{~g}) \\
\text { Fruit }(100 \mathrm{~g}) \\
\text { Rhizome }(250 \mathrm{~g}) \\
\text { Seed }(25 \mathrm{~g}) \\
\text { Seed }(25 \mathrm{~g}) \\
\text { Seed }(25 \mathrm{~g}) \\
\text { Seed }(25 \mathrm{~g}) \\
\text { Seed }(25 \mathrm{~g}) \\
\text { Seed }(25 \mathrm{~g})\end{array}$ & $\begin{array}{l}\text { All the ingredients are powdered, } \\
\text { mixed with } 100 \mathrm{~g} \text { powder of } T \text {. } \\
\text { cordifolia stem and } 25 \mathrm{~g} \mathrm{~K}_{2} \mathrm{CO}_{3} \text {. This } \\
\text { formulation is called neembadi } \\
\text { powder and used to treat various skin } \\
\text { diseases. }\end{array}$ \\
\hline $\begin{array}{l}\text { Dr. Alomgir Moti } \\
\text { Registered doctor }\end{array}$ & $\begin{array}{l}\text { Terminalia chebula } \\
\text { Trachyspermum ammi }\end{array}$ & $\begin{array}{l}\text { Horitoki } \\
\text { Jyno }\end{array}$ & $\begin{array}{l}\text { Combretaceae } \\
\text { Apiaceae }\end{array}$ & $\begin{array}{l}\text { Fruit } \\
\text { Seed }\end{array}$ & $\begin{array}{l}\text { Terminalia chebula (Horitoki), } \\
\text { Trachyspermum ammi (Jyno) powder } \\
\text { is mixed with } T \text {. cordifolia in equal } \\
\text { quantity to make } 50 \mathrm{ml} \text { mixture. } \\
\text { Mixture with salt orally taken to treat } \\
\text { cough. }\end{array}$ \\
\hline $\begin{array}{l}\text { Dr. Mamun Hossain } \\
\text { Registered doctor }\end{array}$ & $\begin{array}{l}\text { Cassia tora } \\
\text { Pongamia pinnata }\end{array}$ & $\begin{array}{l}\text { Chakundi } \\
\text { Karanja }\end{array}$ & $\begin{array}{l}\text { Fabaceae } \\
\text { Fabaceae }\end{array}$ & $\begin{array}{l}\text { Seed }(20 \mathrm{~g}) \\
\text { Seed }(20 \mathrm{~g})\end{array}$ & $\begin{array}{l}\text { All elements are powdered and mixed } \\
\text { with } 5 \mathrm{~g} \text { powder of } T \text {. cordifolia stem. } \\
\text { Used to treat eczema. }\end{array}$ \\
\hline $\begin{array}{l}\text { Dr. Dabir Miah } \\
\text { Registered doctor }\end{array}$ & Brassica campestris & Salghum & Brassicaceae & Seed & $\begin{array}{l}\text { Seed powder mixed with leave paste } \\
\text { of } T \text {. cordifolia. Applied to treat } \\
\text { burning sensation. }\end{array}$ \\
\hline $\begin{array}{l}\text { Md. Khurshed Miah } \\
\text { Kaviraj }\end{array}$ & Piper nigram & Gol morich & Piperaceae & Seed & $\begin{array}{l}\text { Paste of } T \text {. cordifolia stem and five } \\
\text { seeds of Piper nigram (Gol morich), } \\
\text { used to treat Leucorrhoea. }\end{array}$ \\
\hline $\begin{array}{l}\text { Md. Sujon Miah } \\
\text { Street canvasser }\end{array}$ & Solanum surattense & Titbegun & Solanaceae & Root & $\begin{array}{l}\text { Pills made from mixture of } T \text {. } \\
\text { cordifolia stem paste and titbegun } \\
\text { root paste. Taken orally to treat fever. }\end{array}$ \\
\hline $\begin{array}{l}\text { Md. Hatem Ali } \\
\text { Street canvasser }\end{array}$ & $\begin{array}{l}\text { Azadirachta indica } \\
\text { Curcuma longa }\end{array}$ & $\begin{array}{l}\text { Neem } \\
\text { Halud }\end{array}$ & $\begin{array}{l}\text { Meliaceae } \\
\text { Zingiberaceae }\end{array}$ & $\begin{array}{l}\text { Leaf } \\
\text { Rhizome }\end{array}$ & $\begin{array}{l}\text { Paste of stem of } T \text {. cordifolia, } \\
\text { Azadirachta indica (Neem) and } \\
\text { Curcuma longa (Halud), used to treat } \\
\text { various skin diseases. }\end{array}$ \\
\hline
\end{tabular}


In the present investigation, $T$. cordifolia was mainly found to be used in burning sensation and in the treatment of cough, eczema, fever, various skin diseases, leprosy, dysentery, leucorrhoea and pain in ear in the studied area. One Kaviraj (Abdul Mannan) who has been practicing for 20 years reported the use of root and stem of this plant as an antidote to snake and scorpion bite but he did not reveal the way of application.

From the present survey, it was found that stem of $T$. cordifolia was the commonly used part by the three categories of practitioners. From the interview of 17 informants under these practitioners, stem showed the highest percentage of use $(47.06 \%)$ followed by root $(17.64 \%)$, leaves $(11.76 \%)$, combination of root and stem $(11.76 \%)$, fruits $(5.88 \%)$ and whole plant $(5.88 \%)$. Some other plants of different families, frequently used along with T. cordifolia and their formulation used by the practitioners to cure various ailments of human diseases (skin disease, fever, cancer, leprosy, ear pain, snake bite, dysentery, diarrhoea, leucorrhoea, burning sensation, asthma and cough) were also recorded (Table 2).

In the present investigation, registered Ayurvedic doctors in the studied area were found to use stem, leaf, whole plant and the combination of root and stem to treat various ailments while street canvassers used only stem and root for therapeutic purpose (Table 2). On the contrary, kavirajes were found to use different parts of the plant except stem. Scientific studies of Kumar et al. (2000) and Singh et al. (2003) also validated the use of $T$. cordifolia in traditional medicine. It can be concluded that ethnomedicinal use of $T$. cordifolia in Savar Upazila cannot be neglected rather importance should be given to the extensive scientific studies towards discovery of newer formulation to treat diseases.

\section{REFERENCES}

Ahmed, S.M., Hossain, M.A. and Chowdhury, M.R. 2009. Informal sector providers in Bangladesh: how equipped are they to provide rational health care. Health policy plan. 24:467-478.

BBS, 2013. District Statistics 2011, Dhaka. Bangladesh Bureau of Statistics. Ministry of Planning. pp. 13-16.

Bishayi, B., Chowdhury, S., Ghosh, S. and Shengupta, M. 2002. Hepatoprotective and immunomodulatory properties of Tinospora cordifolia in $\mathrm{CCl}_{4}$ intoxicated mature albino rats. J. Toxical Sci. 27: 139-146

Choudhury, N., Siddiqui, M.B., Azmat, S. and Khatoon, S. 2013. Tinospora cordifolia: ethnobotany, phytopharmacology and phytochemistry aspects. Int. J. Pharma. Sci. Res. 4: 891-899.

Jain, S., Sherlekar, B. and Barik, R. 2010. Evolution of antioxidant potential of Tinospora cordifolia and Tinospora sinensis. Int. J. Pharm. Sci. Res. 1: 122-130.

Khory, R.N. and Katrak, N.N. 1981. Materia medica of India and their Therapeutics, pp 31.

Kumar, S., Verma, N.S., Pande, D. and Srivastava, P.S. 2000. In vitro regeneration and screening of berberine in T. cordifolia. J. Med. Aromat. Plant Sci. 22: 61-65.

Martin, G.J. 2008. Ethnobotany: A methods manual. Chapman and Hall, London, pp. 110-112.

Pendse, V.K., Mahavir, M.M., Khanna, K.C. and Somani, S.K. 1981. Antiinflammatory and related activity of Tinospora cordofolia (Neemgiloe). Indian drugs. 19: 14-71. 
Rahman, S.A., Kielmann, T., McPake, B. and Normand, C. 2012. Health care seeking behaviour among the tribal people of Bangladesh: can the current health system really meet their needs. J. Health Popul. Nutr. 30: 353-365.

Singh, J., Sinha, K., Sharma, A., Mishra, N.P. and Khanuja, S.P. 2003. Traditional use of Tinospora cordifolia (Guduchi). J. Med. Aromat. Plant Sci. 25: 748-751.

Uddin, M.Z. and Hassan, M.A. 2014. Determination of informant consensus factor of ethnomedicinal plants used in Kalenga forest, Bangladesh. Bangladesh J. Plant Taxon. 21(1): 83-91. 